\title{
Drug treatment of heart failure
}

\author{
C T DOLLERY, LAURA CORR \\ From the Department of Clinical Pharmacology, Royal Postgraduate Medical School, London
}

In his classic Account of the Foxglove, William Withering gave a vivid description of patients with terminal heart failure and meticulous case reports of their dramatic diuresis in response to digitalis. ${ }^{1}$ Though Withering remarked on the action of digitalis upon the heart he regarded it primarily as a diuretic and did not make the connection between its diuretic and cardiac action. Withering was well aware of the hazards of digitalis overdose but despite his warnings it was widely prescribed in high doses for oedema of non-cardiac origin and for a wide variety of other conditions. Its lack of effect in many of these cases and its pronounced toxicity caused it to fall into disrepute.

In the nineteenth century polypharmacy was in fashion and digitalis was used, if at all, in combination with other agents such as mercury and squill (Baillie's pills; Guy's Hospital pills). ${ }^{2}$ Even early this century the merits and dangers of coffee, strychnine, camphor, and cane sugar in heart failure aroused hot debate. ${ }^{3-5}$ Purgation, cupping, vesication and sweating were widely practised. ${ }^{6}$ The removal of excess fluid was known to produce pronounced clinical improvement and if treatment with digitalis and purgation failed then mechanical means were used. ${ }^{7}$ In the last resort Southey's tubes were used to drain the extracellular fluid, with all their attendant discomfort, scarring, and risk of cellulitis. ${ }^{8}$ Heart failure is an unpleasant illness but the misery inflicted by inappropriate, toxic, or dangerous treatment must often have been greater than that of the disease itself.

Certainly some early treatments, especially venesection, were capable of bringing short term benefits in heart failure. Bloodletting was said to "afford more speedy and compleat relief than any other remedy". 9 But physicians lacked understanding both of the diagnosis and the pathophysiology so that they used different methods without discrimination. Modern physiology established a more rational basis

Requests for reprints to Dr Laura Corr, Department of Clinical Pharmacology, Royal Postgraduate Medical School, London W12 OHS.

«The William Withering Lecture of the Royal College of Physicians, 1985. for treatment. Howarth et al demonstrated haemodynamic improvement after venesection in patients with congestive heart failure who had a very high venous pressure. The cardiac output rose as the venous pressure fell. ${ }^{10}$ The importance of salt and water excess in oedema formation was clarified by Starling in his classic experiments when he perfused isolated animal limbs. ${ }^{11}$ In consequence strict and unpalatable dietary restriction of salt and water was advocated. ${ }^{12-14}$

It was not until Vogl in 1920 reported the diuretic effect of the organomercurial merbaphenum, then a treatment for syphilis, that the era of effective diuretics began. ${ }^{15}$ Mersalyl, a direct development from merbaphenum, was the first effective means of treating oedema. ${ }^{1617}$ Organomercurial diuretics could produce haemodynamic improvement with a rise in cardiac output and a fall in right atrial pressure. ${ }^{18-20}$ Unfortunately they had to be administered parenterally and were toxic. Local tissue necrosis followed a badly placed injection and chronic administration produced manifestations of mercurialism which varied from stomatitis to the nephrotic syndrome. ${ }^{21-25}$ Hypersensitivity reactions although uncommon were occasionally fatal. ${ }^{2627}$

The search for an orally effective diuretic continued, but most of those produced were relatively ineffective. ${ }^{28-31}$ Just as astute clinical observations during the use of merbaphenum in syphilis led to the development of mersalyl, so clinical observations of a diuresis during treatment with antibacterial sulphonamides were to lead eventually to the discovery of the benzothiadiazine diuretics. The synthesis of chlorothiazide by Novello and Sprague in $1957^{32}$ was the most important single advance in the symptomatic relief of heart failure. Although less potent than the organomercurials, ${ }^{33}$ the thiazides were effective orally even in those patients who had become resistant to mercurial diuretics and they were also much less toxic. ${ }^{3435}$ They were not, however, without their problems. One of their major side effects was hypokalaemia which could be profound, ${ }^{36}$ inducing hepatic coma in patients with cirrhosis $^{37}$ and sensitising the myocardium to the toxic effects of digitalis in patients with congestive cardiac failure. ${ }^{38-40}$ None the less, they remain an 
important tool in the management of heart failure.

Diuretic resistance remained common until the era of the so called "loop" diuretics frusemide and ethacrynic acid. These are both extremely potent and quite well tolerated. ${ }^{41-44}$ Their efficacy, even in those patients who no longer respond to thiazides, means that the diuretic resistant patient is now rare. ${ }^{45}$

The salt retaining corticosteroid, aldosterone, was identified ${ }^{\mathbf{4 6}}$ at almost the same time as the discovery of the oral diuretics. For many years it was believed that secondary hyperaldosteronism was mainly responsible for the salt and water retention in congestive heart failure and much research was concentrated on this mechanism. Spironolactone (a specific aldosterone antagonist), however, proved to be relatively ineffective in cardiac oedema. The position was finally clarified in 1974 by Nicholls et al who showed that aldosterone concentrations were slightly raised in untreated heart failure and fell to normal as body weight declined during diuretic therapy. ${ }^{47}$ It was only as the body weight stabilised and the patient became salt depleted that the aldosterone levels rose sharply to 4-6 times normal. Knight et al demonstrated a highly significant correlation between the dose of frusemide and the plasma aldosterone concentration. ${ }^{48}$

Release of renin from the kidney is critical and there appears to be a two stage mechanism. In heart failure renal blood flow is slightly reduced and an increase in renin release follows. Circulating angiotensin II stimulates aldosterone secretion from the adrenal and plasma aldosterone becomes slightly raised. As patients become salt depleted and "dried out" there is a secondary and much greater rise in renin and aldosterone. ${ }^{47}$

Modern diuretics have transformed the symptomatic treatment of a patient with dropsy and would have greatly impressed a physician of Withering's era. But they are only part of the story and are not without their problems. The patient who has been dried out with diuretics may look better but the other problems of heart failure remain-fatigue, limited exercise capacity, cachexia, and salt depletion with a high plasma aldosterone and renin. A fully effective treatment for heart failure should restore exercise capacity and improve life expectancy as well as relieve symptoms.

\section{Exercise capacity}

With the advent of invasive haemodynamic monitoring, ${ }^{4-51}$ the effect of drug treatment on different aspects of the failing circulation became clearer. ${ }^{5253}$ Unfortunately, most studies were performed in the catheter laboratory and the obser- vations lasted at most a few hours. They yielded valuable information on the control of the cardiovascular system but were a poor guide to long term therapeutic responses. ${ }^{54}$ Haemodynamic indices such as cardiac output correlate very poorly with exercise duration and capacity in patients with heart failure. ${ }^{556}$ More sophisticated haemodynamic indices, even those determined during exercise testing also fail to show any significant correlation with exercise capacity. ${ }^{57-59}$

Attempts to improve exercise capacity in heart failure must take into account normal circulatory control during exertion. Cardiac output at rest is normally about 5-6 litres of which about half goes to the splanchnic and renal beds and a quarter to skeletal muscle. Under conditions of maximal exercise there is an enormous increase in cardiac output (for example to 24 litres) primarily to skeletal muscle. ${ }^{60}$ In addition a rationing system is introduced which curtails the flow to inactive muscle and the splanchnic and renal beds while allowing the coronary flow to rise and the cerebral blood flow to remain virtually unchanged. Mason et al have demonstrated that the rationing system imposed on the normal circulation during exercise is active in heart failure patients at rest. ${ }^{61}$ The total cardiac output at rest is generally lower with more going to skeletal muscle and less to the renal and splanchnic beds. During exercise, this imbalance becomes even more pronounced.

There is one further adaptation of the circulation in heart failure. Franciosa showed that for a given workload the oxygen consumption of a group of patients with congestive cardiac failure of varying severity is virtually identical to that of a group of normal controls. ${ }^{62}$ At each workload, however, the cardiac index of the patients with congestive cardiac failure was lower than in the controls, indicating increased extraction of oxygen from the capillary blood. The main difference between controls and those with heart failure of different degrees of severity was the load/duration at which they had to stop.

An objective measure of maximal exercise capacity, such as the maximal oxygen uptake, is desirable for the comparison of different drugs used in the treatment of heart failure. Maximal oxygen uptake is a sensitive test for differentiating the severity of heart failure. ${ }^{62}$ Unfortunately in most of the protocols used for testing exercise capacity in patients with congestive cardiac failure the workload is doubled every few minutes. ${ }^{63-65}$ Such protocols may be appropriate for theshold testing in patients with angina, but they have the effect of telescoping the variation in duration of exercise at higher workloads in patients with congestive cardiac failure and of reducing the sensitivity of the method for detecting benefit. A fixed workload, if necessary one calculated 
individually for each subject, would be more appropriate.

\section{CRITERIA FOR ACCEPTABLE STUDIES}

In our review of the vast number of published reports on the drug treatment of congestive heart failure we have concentrated on studies which were double blind, included a placebo control, and assessed the effect of treatment upon exercise capacity. We have included only those studies which assessed longer term effects of drug therapy on exercise capacity, since these have been shown to differ from short term effects. ${ }^{66}$ Unfortunately we have therefore had to exclude many papers. Ideally we should have applied two further exclusion criteria-firstly that the numbers of patients studied were sufficiently large to have confidence in the significance of a negative result, that is to say that the study included a calculation of statistical power as well as significance; and secondly that the results were analysed on an intention to treat basis rather than on the basis of the patients who completed the protocol. Had we applied these additional criteria too few papers would have been left for conclusions to be drawn.

Two broad categories of drugs have been used to try to increase exercise capacity in patients with heart failure; these are vasodilators and positive intropic agents.

\section{VASODILATOR THERAPY}

Vasodilators were introduced into the treatment of heart failure as a result of haemodynamic research and with the aim of reducing preload and afterload. ${ }^{6768}$ They have profound immediate haemodynamic effects and were hailed by many as the most important advance in treatment since digitalis and the diuretics. Despite the improved haemodynamics associated with their use, short term studies did not always show an increase in exercise capacity.$^{69}$ Moreover, the effect of long term treatment on exercise capacity was neglected until the past decade.

A wide spectrum of vasodilator drugs is currently in use, the most common groups being direct acting venodilators (such as nitrates), arteriolar dilators (such as hydralazine), alpha ${ }_{1}$ adrenoceptor blocking drugs (for example prazosin, trimazosin), and the angiotensin converting enzyme inhibitors (captopril, enalapril). The beta ${ }_{2}$ receptor agonists, such as salbutamol, are now thought to be too arrhythmogenic for widespread use.

In a randomised double blind placebo controlled study of 32 patients followed up over 26 weeks, Franciosa et al found a significant improvement in exercise duration on hydralazine over the first four weeks (mean (SEM) 259(21) to 347(35) s, p <0.01) and a further rise at 26 weeks $(421(38) \mathrm{s}, \mathrm{p}<0.001) .^{70}$ Exercise duration, however, also increased significantly in the placebo group over the first four weeks (271(30) to $340(44) \mathrm{s}, \mathrm{p}<0.02)$ and at 26 weeks $(339(46) \mathrm{s}, \mathrm{p}<0.02)$. There were no significant differences between the two groups at any time during the study and this evidence emphasises the need for adequate placebo controls. In a further study with hydralazine by Conradson et al, the difference between the treated and control group just reached statistical significance at six months $(p<0.05)$ but this advantage was lost by 12 months $(p=0 \cdot 14){ }^{71}$ Only half of the patients who entered the study completed it; most dropped out because of worsening heart failure. If the results had been analysed on an intention to treat rather than the on treatment basis it is unlikely that there would have been a significant difference between the two groups.

Similar results were reported by Leier et al with isosorbide dinitrate in a study of 30 patients over 12 weeks. ${ }^{72}$ Both the treated and the control groups showed a small increase in their exercise duration, with the difference just reaching statistical significance at 90 days. A similar trend was seen with prazosin over six months' treatment (mean (SD)) (541(204) to 630(100) s) compared with placebo (531(141) to $435(148) \mathrm{s}$ ), but the difference between the groups was not significant. ${ }^{73}$ Other studies with prazosin and trimazosin have shown a small improvement in the treated group over baseline values which was not seen in the placebo group but in most cases the difference in improvement between the groups was not significant. ${ }^{74-76}$

Whether or not the improvement on vasodilators was just significant, the disappointing fact remains that the degree of improvement so far demonstrated with vasodilators is not of sufficient magnitude to make a substantial difference to the patient's life. It is debatable whether the improvement in most of the trials would be of any real clinical value.

The last category of drugs included, somewhat loosely, under the heading of vasodilators is the angiotensin converting enzyme inhibitors. Here the results are somewhat more encouraging. Cleland et al found a highly significant increase in exercise time from $336(228)$ to $546(318) \mathrm{s}(\operatorname{mean}(\mathrm{SD}))(\mathrm{p}<0.005)$ in 14 patients after 12 weeks' therapy with captopril. With placebo substitution, exercise time fell to 456(258) s $(p<0.03) .{ }^{77}$ A less pronounced improvement was seen in a similar study by Cowley et al (mean (SEM)) $(726(77 \cdot 4)$ to $894(70 \cdot 2)$ s, $\mathrm{p}<0.05$ ) but they studied patients with milder heart failure over a shorter period of four weeks. ${ }^{78} \mathrm{~A}$ much larger multicentre study with 92 patients over 12 weeks showed a $24 \%$ increase in exercise tolerance (495(22) to $614(27)$ s) with captopril as compared 
with a $0.4 \%$ increase with placebo (mean (SEM)) $(480(28)$ to $483(43) \mathrm{s}, \mathrm{p}<0.01) .{ }^{79}$ Furthermore the difference between the two groups became more pronounced as the study continued, and the exercise tolerance of the treated group was still rising at 12 weeks. The largest study of an angiotensin converting enzyme inhibitor was an international multicentre study of enalapril in 256 patients. Again the treated group had significantly better exercise tolerance than the placebo group at 12 weeks and the difference continued to increase up to 24 weeks $(\mathrm{p}<0.001)$.

Angiotensin converting enzyme inhibitors may be the only group of "vasodilators" which offer a real advantage for patients in heart failure. Besides their effect upon peripheral vascular resistance they also reduce aldosterone secretion and have a mild diuretic action in contrast to the salt retaining action of all other vasodilators.

\section{INOTROPES}

For almost 200 years the mainstay of treatment for congestive heart failure has been inotropic therapy with digoxin. With reservations about the dangers of increased myocardial oxygen demand, the use of drugs with a positive inotropic action to increase the low cardiac output of heart failure appears the most promising therapeutic approach. Powerful inotropes such as isoprenaline increase the resting cardiac index ${ }^{80}$ but their value in the management of patients with chronic congestive cardiac failure is not established. Despite its long history, controlled trials of digoxin treatment in patients with congestive heart failure who are in sinus rhythm were not done until the value of such treatment began to be questioned about 10 years ago. Since then scepticism has grown after several studies in which either no benefit could be demonstrated or, if present, was very small. $^{81-83}$ Some studies such as those by Lee et al ${ }^{84}$ and Arnold et al ${ }^{85}$ have shown clinical or haemodynamic benefit, but maximal exercise capacity was not improved in a non-randomised, double blind, placebo controlled withdrawal study of $12 \mathrm{pa}$ tients by Fleg et al ${ }^{86}$ According to the criteria we have adopted, a benefit of digitalis in patients with heart failure treated with diuretics has not been established.

Most of the more powerful inotropic agents approved for clinical use have to be given intravenously and thus cannot be used routinely in long term outpatient management of congestive heart failure. To overcome this disadvantage several orally active positive inotropes, such as the bipyridine derivatives amrinone and milrinone, have been developed and have generated intense interest. ${ }^{87}$ Amrinone showed some initial promise when Weber et al reported a sustained increase in maximal oxygen consumption in patients taking the drug orally for 12 weeks. ${ }^{88}$ But a lack of improvement seen in small studies ${ }^{89}$ has been confirmed by the findings of a much larger multicentre study of 173 patients. ${ }^{90}$ The 52 patients who showed the best response to the drug in the open phase were randomised in a double blind fashion to either continue amrinone or to receive placebo. Subsequent comparison of the two groups showed similar falls in exercise time (7\% and $10 \%$ respectively) and no significant difference between them. The lack of long term efficacy coupled with a high incidence of adverse reactions has prompted the withdrawal of amrinone from clinical trials except as acute intravenous therapy. We await the results of trials with its congener, milrinone.

Unexpected encouragement to continue the search for better inotropic agents has come from studies of the intravenous administration of dobutamine. Liang et al studied 15 patients with congestive cardiomyopathy who were given 72 hour infusions of dobutamine or placebo in a randomised double blind placebo controlled trial which included measurement of exercise capacity over four weeks. ${ }^{91}$ There was a significant difference in treadmill exercise time between the two groups which was sustained over four weeks $(p<0.05)$. Though it is difficult to postulate a mechanism for this long duration of action, some support for the findings comes from a previous uncontrolled study of intermittent shorter infusions given to outpatients weekly for 24 weeks. ${ }^{92}$ Dobutamine looks reasonably promising but we must await the outcome of larger controlled trials before the benefits and the effects of mortality and morbidity can be assessed.

Overall the effects of vasodilators and positive inotropic agents in heart failure are unimpressive when measured against the extent of the patient's disability. The degree of benefit, however, that can be attained must ultimately be limited by the severity and reversibility of the damage to the heart muscle.

\section{Prolongation of life}

An effective treatment of heart failure ought to prolong life as well as provide symptomatic relief. It is instructive to examine the evidence that any form of treatment can improve survival.

\section{PROGNOSIS OF HEART FAILURE}

The prognosis of congestive heart failure is as grave as that of many malignant neoplasms. In the Framingham study overt evidence of congestive heart failure developed in 142 of the original cohort of 5192 over 16 years. ${ }^{93}$ Despite medical management the probability of dying within five years from the onset 
of heart failure was $62 \%$ for men and $42 \%$ for women. Mortality rates of about $35 \%$ at one year were found in several smaller studies by Massie et al, ${ }^{94}$ Franciosa et al,${ }^{95}$ and Unverferth et al. ${ }^{96}$ The cumulative mortality of medically refractory heart failure is even worse $-42 \%$ at one year and $68 \%$ at two years. ${ }^{97}$

Patients with heart failure do not all die from a progressively falling cardiac output; sudden death is also important. Wilson et al, who defined a death as sudden if the patient was known to have been clinically unchanged in the previous week and stable one hour before death, reported that approximately $50 \%$ of deaths were sudden and that the rest were due to progressive heart failure. ${ }^{97}$ Other estimates of mortality attributable to sudden death vary from $11 \%$ to $60-90 \% .{ }^{98-100}$

It is interesting that the Beta-blocker Heart Attack Trial showed a reduction in the relative mortality rate for patients with mechanical as well as electrical complications of acute myocardial infarction who were treated with propranolol. ${ }^{101}$ Prevention of sudden death from arrhythmias may provide a means of improving survival in patients with congestive heart failure.

No properly designed studies have been carried out to investigate the effects of vasodilators or positive inotropic agents upon mortality. Pooling the published controlled studies suggests that mortality with most drugs (for example, alpha blockade, hydralazine, isosorbide) is either unchanged or increased. The combined data from the much larger trials with the angiotensin converting enzyme inhibitors captopril and enalapril are more encouraging. The effect of the angiotensin converting enzyme inhibitors on mortality in heart failure should now be investigated in a large properly designed trial.

Tunstall Pedoe studied changes in national mortality statistics over two periods when the bioavailability of digoxin was changed. ${ }^{102}$ There was little change in the dose of digoxin prescribed over these periods and no consistent change in mortality. This implies that the increased bioavailability of digoxin itself was not an important cause of mortality, but neither was it beneficial.

\section{PREVENTION OF HEART FAILURE}

There is evidence that some deaths from heart failure may be preventable. The Medical Research Council Home Oxygen Trial showed that 19 of the 42 patients with chronic hypoxic cor pulmonale who were treated with long term oxygen therapy died in the five years of survival follow up compared with 30 of the 45 controls. ${ }^{103}$ In the Veterans Administration Study of cor pulmonale $88 \%$ of the responders to home oxygen (that is those who had a fall in their mean pulmonary arterial pressure) but only $22 \%$ of the non-responders were alive at the end of two years. ${ }^{104}$ These trials, however, involved patients taking oxygen at home for at least 15 hours a day and the quality of the life that was prolonged must have been much restricted.

There is one further area where preventive treatment seems to have led to a major reduction in mortality from cardiac failure. This is the treatment of hypertension. Several therapeutic trials in patients with severe hypertension ${ }^{105-107}$ showed that adequate control of blood pressure prevents the development of heart failure. It is noteworthy that in the Framingham study hypertension preceded the development of heart failure in $75 \%$ of cases. ${ }^{93}$ Further evidence is provided by a review of the mortality data for England and Wales from the Registrar General's annual reports under code 402 (deaths from hypertensive heart disease). While there must be some reservations about the possible alternative coding in another category of deaths from this cause, the

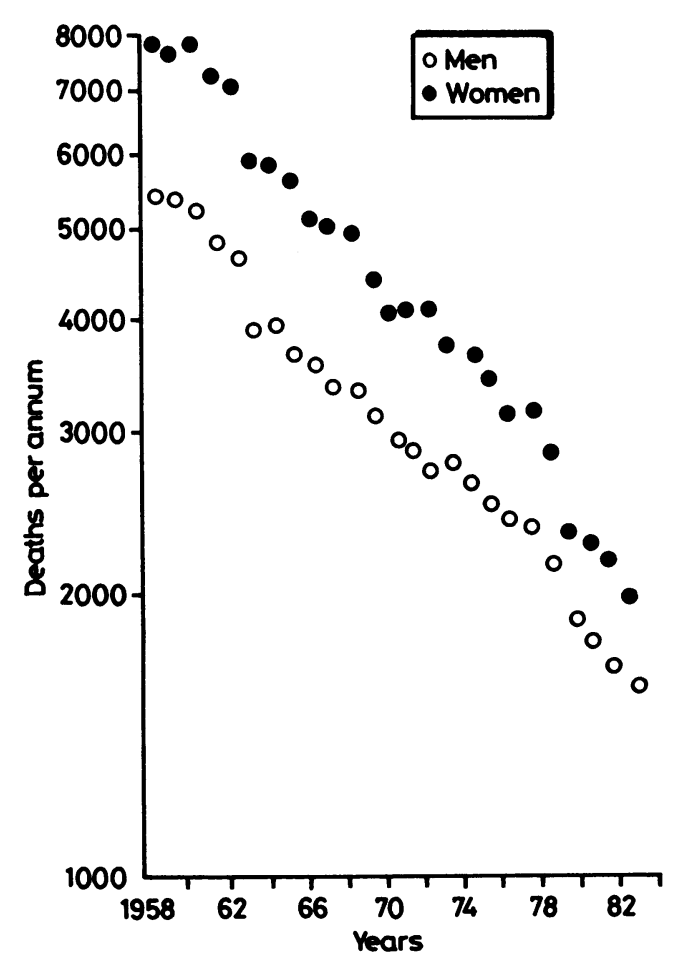

Fig. Mortality from hypertensive heart disease in England and Wales since 1958. (Source: Code 402 from the Registrar General's annual reports.) 
figures show a $75 \%$ fall in mortality from hypertensive heart disease since 1958 and deaths in those with hypertensive heart disease are probably mainly caused by heart failure (see Fig.).

\section{Future prospects}

Despite the success of diuretics, it is a sobering thought that other advances in therapeutics over the last 200 years such as the discovery of penicillin and the treatment of tuberculosis would impress a physician of Withering's era far more than our use of vasodilators and inotropes for chronic heart failure. Indeed Withering himself, a forward thinking member of the Lunar Society, would probably be dismayed to find that we are still using digitalis, a drug which he recognised to be highly toxic and of limited efficacy. Perhaps only the angiotensin converting enzyme inhibitors and the modern management of hypertension would provide him with some faith in our progress in the treatment of heart failure.

The best hope for the future is probably to concentrate on preventive measures such as reduction in cigarette smoking, treatment of hypertension, myocardial salvage during infarction, and even the prevention of atheroma. There may also be some scope to improve active treatment by combining inotropes with angiotensin converting enzyme inhibitors and perhaps by combining the inotropic action of a drug like dobutamine with the antiarrhythmic action of propranolol in a molecule which is a partial beta receptor agonist. Heart failure will have to be treated less as a global end stage disease and more as the specific outcome of diseases such as ischaemic heart disease and cardiomyopathy. Continued advances in treatment are much needed.

\section{References}

1 Withering W. An account of the foxglove, and some of its medical uses: with practical remarks on dropsy, and other diseases. London: GGJ and J Robinson, 1785.

2 Vogl A. Diuretic therapy: the pharmacology of diuretic agents and the clinical management of the edematous patient. Baltimore: Williams and Wilkins, 1953.

3 Schott T. Diet in chronic heart disease. Lancet 1904; ii: $138-9$.

4 Harris I. Intra-cardiac pressure as a standard in cardiotherapy. Lancet 1920; i: 954-7.

5 Goulston A. West Indian cane sugar in the treatment of certain forms of heart disease. $\mathrm{Br}$ Med $\mathcal{F}$ 1912; ii: 693-5.

6 Barr J. General principles in the treatment of diseases of the heart. $\mathrm{Br} \mathrm{Med} \mathcal{F} 1909$; i: 989-95.

7 Southey R. Chronic parenchymatous nephritis of right kidney. Left kidney small and atrophied. Old seraph- ulous pyelitis. Trans Clin Soc Lond 1877; 10: 152-7.

8 Walsh AC, Moyes A. Intractable congestive heart failure successfully treated with Southey's tubes [Letter]. Can Med Assoc f 1964; 90: 1375-6.

9 Warren JC. Cases of organic diseases of the heart. Boston: TB Wait and Co, 1809.

10 Howarth S, McMichael J, Sharpey-Schafer EP. Effects of venesection in low output heart failure. Clin Sci 1946; 6: 41-50.

11 Starling EH. On the absorption of fluids from the connective tissue spaces. I Physiol (Lond) 1896; 19: 312-26.

12 Achard MC, Loeper M. Sur a rétention des chlorures dans les tissus au cours de certains états morbides. $C$ $R$ Soc Biol (Paris) 1901; 53: 346-7.

13 Peters JP. The role of sodium in the production of edema. $N$ Engl f Med 1948; 239: 353-62.

14 Schroeder HA. Studies on congestive heart failure. I. The importance of restriction of salt as compared to water. Am Heart $\mathcal{F} 1941$; 22: 141-53.

15 Vogl A. Gesellschaft der Arzte in Wien: Offizielles Sitzungsprotokoll vom 6 Februar 1920. Wien Klin Wochenschr 1920; 33: 197-9.

16 Saxl P. Verhandlungen ärtzlicher Gesellschaften und Kongressberichte. Wien Klin Wochenschr 1920; 33: 179-80.

17 Pitts RF. Some reflections on mechanisms of action of diuretics. Am f Med 1958; 24: 745-63.

18 Pugh LGC, Wyndham CL: The circulatory effects of mercurial diuretics in congestive heart failure. Clin Sci 1949; 8: 11-9.

19 Scebat L, Maurice $P$, Lenègre J. L'action d'un diurétique mercuriel sur la pression sanguine des cavités droites du coeur chez les cardiaques. Arch Mal Coeur 1949; 42: 1149-53.

20 Volini IF, Levitt RO. Studies on mercurial diuresis. II. The immediate effect on the venous blood pressure. Am Heart f 1939; 17: 187-93.

21 Bruno MS. Fatal toxic nephrosis following administration of mercurial diuretics. $N$ Engl F Med 1948; 239: 769-73.

22 Grossman J, Weston RE, Lehman RA, Halperin JP, Ullmann TD, Leiter L. Urinary and fecal excretion of mercury in man following administration of mercurial diuretics. F Clin Invest 1951; 30: 1208-20.

23 Siegel MB, Friedman AJ. Fatal mercurialism due to prolonged intravenous administration of a mercurial diuretic. Ann Intern Med 1949; 31: 343-53.

24 Waife SO, Pratt PT. Fatal mercurial poisoning following prolonged administration of mercurophylline. Arch Intern Med 1946; 78: 42-8.

25 De Graff AC, Nadler JE. A review of the toxic manifestations of mercurial diuretics in man. $\mathcal{F} A M A 1942$; 119: 1006-11.

26 Hyman HT. Sudden deaths after use of mercurial diuretics. FAMA 1942; 119: 1444-7.

27 Kaufman RE. Immediate fatalities after intravenous mercurial diuretics. Ann Intern Med 1948; 28: 1040-7.

28 Counihan TB, Evans BM, Milne MD. Observations on the pharmacology of the carbonic anhydrase inhibitor "diamox". Clin Sci 1954; 13: 583-98.

29 Hanley T, Platts MM. Acetazolamide (Diamox) in the 
treatment of congestive heart failure. Lancet 1956; i: 357-9.

30 Relman AS, Leaf A, Schwartz WB. Oral administration of a potent carbonic anhydrase inhibitor (" $\mathrm{Di}$ amox"). II. Its use as a diuretic in patients with severe congestive heart failure. $N$ Engl f Med 1954; 250: 800-4.

31 Wener J, Knight A. Some observations on a new oral diuretic, mictine. Can Med Assoc f 1957; 76: 952-4.

32 Novello FC, Sprague JM. Benzothiadiazine dioxides as novel diuretics. F Am Chem Soc 1957; 79: 2028-31.

33 Ford RV. Clinical pharmacology of diuretic agents with special reference to chlorothiazide (Divril). Dis Chest 1960; 37: 418-29.

34 Bayliss RIS, Pirkis J, Marrack D, Rees JR, Zilva JF. Chlorothiazide: an oral diuretic. Lancet 1958; i: 120-4.

35 Slater JDH, Nabarro JDN. Clinical experience with chlorothiazide. Lancet 1958; i: 124-7.

36 Sherlock S, Read AE, Laidlaw JL, Haslam R. Chlorothiazide in liver disease. Ann NY Acad Sci 1958; 71: 430-7.

37 Myerson RM, Stout RE, Forte AL. Acetazolamide and chlorothiazide in the treatment of ascites due to cirrhosis of the liver. $N$ Engl 7 Med 1959; 260: 28-30.

38 Cohen T. Hypokalemic muscle paralysis associated with administration of chlorothiazide. $\mathcal{F} A M A 1959$; 170: 2083-5.

39 Richman JL. Digitalis intoxication induced by chlorothiazide. Bull Tufts - N Engl Med Center 1960; 6: 18-30.

40 Fries ED. Treatment of hypertension with chlorothiazide. $\mathcal{F} A M A$ 1959; 169: 105-8.

41 Stokes W, Nunn LCA. A new effective diuretic Lasix. Br Med f 1964; ii: 910-4.

42 Verel D, Stentiford NH, Rahman F, Saynor R. A clinical trial of frusemide. Lancet 1964; ii: 1088-92.

43 Hutcheon DE, Mehta D, Romano A. Diuretic action of furosemide. Arch Intern Med 1965; 115: 542-56.

44 Statson WB, Cannon PJ, Heinemann HO, Laragh JH. Furosemide. A clinical evaluation of its diuretic action. Circulation 1964; 34: 910-20.

45 Dollery CT, Parry EHO, Young DS. Diuretic and hypotensive properties of ethacrynic acid: a comparison with hydrochlorothiazide. Lancet 1964; i: 947-52.

46 Grundy HM, Simpson SA, Tait JF. Isolation of a highly active mineralocorticoid from beef adrenal extract. Nature 1952; 169: 795-6.

47 Nicholls MG, Espiner EA, Donald RA, Hughes H. Aldosterone and its regulation during diuresis in patients with gress congestive cardiac failure. Clin $\mathrm{Sci}$ Mol Med 1974; 47: 301-15.

48 Knight RK, Miall PA, Hawkins LA, Dacombe J, Edwards CRW, Hamer J. Relation of plasma aldosterone concentration to diuretic treatment in patients with severe heart disease. Br Heart $\mathcal{F}$ 1979; 42: 316-25.

49 Forssmann $W$. Die Sondierung des rechten Herzens. Klin Wochenschr 1929; 8: 2085-7, 2287.

50 Cournand AF, Ranges HA. Catheterization of the right auricle in man. Proc Soc Exp Biol Med 1941; 46: 462-6.

51 Richards DW. The contributions of the right heart catheterization to physiology and medicine, with some observations on the pathophysiology of pulmonary heart disease. Am Heart $\mathcal{F}$ 1957; 54: 161-71.

52 Swan HJC, Ganz W, Forrester JS, Marcus H, Diamond $G$, Chonette $D$. Catheterization of the heart in man with the use of a flow-directed balloon-tipped catheter. N Engl f Med 1970; 283: 447-51.

$53 \mathrm{McMichael} \mathrm{J}$. Circulatory failure studied by means of venous catheterization. Adv Intern Med 1947; 2: 64-101.

54 Franciosa JA, Mikulic E, Cohn JN, Jose E, Fabie A. Hemodynamic effects of orally administered isosorbide dintrate in patients with congestive heart failure. Circulation 1974; 50: 1020-4.

55 Rubin SA, Chatterjee K, Gelberg HJ, Ports TA, Brundage BH, Parmley WW. Paradox of improved exercise but not resting hemodynamics with short term prazosin in chronic heart failure. Am $\mathcal{f}$ Cardiol 1979; 43: 810-5.

56 Franciosa JA, Ziesche S, Wilen M. Functional capacity of patients with chronic left ventricular failure. $\mathrm{Am}$ f Med 1979; 67: 460-6.

57 Engler R, Ray R, Higgins CB, et al. Clinical assessment and follow-up of functional capacity in patients with chronic congestive cardiomyopathy. Am $\mathrm{f}$ Cardiol 1982; 49: 1832-7.

58 Franciosa JA, Park M, Levine TB. Lack of correlation between exercise capacity and indexes of resting left ventricular performance in heart failure. $\mathrm{Am} \mathcal{f}$ Cardiol 1981; 47: 33-9.

59 Szlachcic J, Massie BM, Kramer BL, Topic N, Tubau $\mathrm{J}$. Correlates and prognostic implications of exercise capacity in chronic congestive heart failure. Am $\mathcal{Y}$ Cardiol 1985; 55: 1037-42.

60 Mitchell JH, Blomqvist G. Maximal oxygen uptake. $N$ Engl f Med 1971; 284: 1018-22.

61 Mason DT, Zelis R, Longhurst J, Lee G. Cardiocirculatory responses to muscular exercise in congestive heart failure. Prog Cardiovasc Dis 1977; 19: 475-89.

62 Franciosa JA. Exercise testing in chronic congestive heart failure. Am $\mathcal{F}$ Cardiol 1984; 53: 1447-50.

63 Bruce RA. Exercise testing for evaluation of ventricular function. $N$ Engl f Med 1977; 296: 671-5.

64 Astrand PO. Quantification of exercise capability and evaluation of physical capacity in man. Prog Cardiovasc Dis 1976; 19: 51-67.

65 Patterson JA, Naughton J, Pietras RJ, Gunnar RM. Treadmill exercise in assessment of the functional capacity of patients with cardiac disease. Am $\mathcal{F}$ Cardiol 1972; 30: 757-62.

66 Franciosa JA, Goldsmith SR, Cohn JN. Contrasting immediate and long-term effects of isosorbide dinitrate on exercise capacity in congestive heart failure. Am $\mathcal{Y}$ Med 1980; 69: 559-66.

67 Braunwald E. Vasodilator therapy - a physiologic approach to the treatment of heart failure. $N$ Engl $\mathcal{F}$ Med 1977; 297: 331-3.

68 Mason DT. Symposium on vasodilator and inotropic therapy of heart failure. Symposium perspective. $\mathrm{Am}$ f Med 1978; 65: 101-5.

69 Franciosa JA, Cohn JN. Immediate effects of 
hydralazine-isosorbide dinitrate combination on exercise capacity and exercise hemodynamics in patients with left ventricular failure. Circulation 1979; 59: 1085-91.

70 Franciosa JA, Weber KT, Levine TB, et al. Hydralazine in the long term treatment of chronic heart failure: lack of difference from placebo. Am Heart $\mathfrak{f}$ 1982; 104: 587-94.

71 Conradson T-B, Rydén L, Ahlmark G, et al. Clinical efficacy of hydralazine in chronic heart failure: one year double-blind placebo controlled study. Am Heart f 1984; 108: 1001-6.

72 Leier CV, Huss P, Magorien RD, Unverferth DV. Improved exercise capacity and differing arterial and venous tolerance during chronic isosorbide dinitrate therapy for congestive heart failure. Circulation 1983; 67: 817-22.

73 Higginbotham MB, Morris KG, Bramlet DA, Coleman RE, Cobb FR. Long-term ambulatory therapy with prazosin versus placebo for chronic heart failure: relation between clinical response and left ventricular function at rest and during exercise. Am $\mathcal{f}$ Cardiol 1983; 52: 782-8.

74 Aronow WS, Greenfield RS, Alimadadian H, Danahy DT. Effect of the vasodilator trimazosin versus placebo on exercise performance in chronic left ventricular failure. Am $\mathcal{f}$ Cardiol 1977; 40: 789-93.

75 Weber KT, Kinasewitz GT, West JS, Janicki JS, Reichek N, Fishman AP. Long-term vasodilator therapy with trimazosin in chronic cardiac failure. $N \mathrm{Engl}$ f Med 1980; 303: 242-50.

76 Colucci WS, Wynne J, Holman BL, Braunwald E. Long-term therapy of heart failure with prazosin: a randomized double blind trial. Am F Cardiol 1980; 45: 337-44.

77 Cleland JGF, Dargie HJ, Hodsman GP, et al. Captopril in heart failure: a double blind controlled trial. Br Heart $\mathcal{F} 1984$; 52: 530-5.

78 Cowley AJ, Rowley JM, Stainer KL, Hampton JR. Captopril therapy for heart failure. A placebo controlled study. Lancet 1982; ii: 730-2.

79 Captopril Multicenter Research Group. A placebo controlled trial of captopril in refractory chronic congestive heart failure. $f \mathrm{Am}$ Coll Cardiol 1983; 2: 755-63.

80 Kersting F, Follath F, Moulds R, et al. A comparison of cardiovascular effects of dobutamine and isoprenaline after open-heart surgery. Br Heart $\mathcal{f} 1976$; 38: 622-6.

81 Johnston GD, McDevitt DG. Is maintenance digoxin necessary in patients with sinus rhythm? Lancet 1979; i: $567-70$.

82 McHaffie D, Purcell H, Mitchell-Heggs P, Guz A. The clinical value of digoxin in patients with heart failure and sinus rhythm. $Q \mathcal{F}$ Med 1978; 47: 401-19.

83 Dobbs SM, Kenyon WI, Dobbs RJ. Maintenance digoxin after an episode of heart failure: placebo controlled trial in outpatients. $\mathrm{Br}$ Med $\mathcal{F} 1977$; i: 749-52.

84 Lee DC, Johnson RA, Bingham JB, et al. Heart failure in out-patients. A randomized trial of digoxin versus placebo. N Engl f Med 1982; 306: 699-705.

85 Arnold SB, Byrd RD, Meister W, et al. Long-term digitalis therapy improves left ventricular function in heart failure. $N$ Engl f Med 1980; 303: 1443-8.

86 Fleg JL, Gottlieb SH, Lakatta EG. Is digoxin really important in the treatment of compensated heart failure? Am $F$ Med 1982; 73: 244-50.

87 Wynne J, Braunwald E. New treatment for congestive heart failure: amrinone and milrinione. $\boldsymbol{f}$ Cardiovasc Med 1984; 9: 393-405.

88 Weber KT, Andrews V, Janicki JS. Cardiotonic agents in the management of chronic cardiac failure. Am Heart $\mathcal{F}$ 1982; 103: 639-49.

89 Evans JR, Pacht K, Huss P, Unverforth DV, Bashore TM, Leier CV. Chronic oral amrinone therapy in congestive heart failure. A double blind placebocontrolled withdrawal study. Int $\mathcal{F}$ Clin Pharmacol Res 1984; 4: 9-18.

90 Di Bianco R, Shabetai R, Silverman BD, Leier CV, Benotti JR, with the Amrinone Multicenter Study Investigation. Oral amrinone for the treatment of chronic congestive heart failure; results of a multicentre randomised double-blind, placebo controlled withdrawal study. $f$ Am Coll Cardiol 1984; 4: 855-66.

91 Liang CS, Sherman LG, Doherty JU, Wellington K, Lee VW, Hood WB Jr. Sustained improvement of cardiac function in patients with congestive heart failure after short term infusion of dobutamine. Circulation 1984; 69: 113-9.

92 Leier CV, Huss P, Lewis RP, Unverferth DV. Druginduced conditioning in congestive heart failure. Circulation 1982; 65: 1382-7.

93 McKee PA, Castelli WP, McNamara PM, Kannel WB. The natural history of congestive heart failure: the Framingham Study. $N$ Engl $f$ Med 1971; 285: 1441-6.

94 Massie B, Ports T, Chatterjee K, et al. Long-term vasodilator therapy for heart failure: clinical response and its relationship to hemodynamic measurements. Circulation 1981; 63: 269-78.

95 Franciosa JA, Wilen M, Ziesche S, Cohn JN. Survival in men with severe chronic left ventricular failure due either to coronary heart disease or idiopathic dilated cardiomyopathy. Am f Cardiol 1983; 51: 831-6.

96 Unverferth DV, Magorien RD, Moeschberger ML, Baker PB, Fetters JK, Leier CV. Factors influencing the one-year mortality of dilated cardiomyopathy. Am 7 Cardiol 1984; 54: 147-52.

97 Wilson JR, Schwartz JS, Sutton MS, et al. Prognosis in severe heart failure. Relation to hemodynamic measurements and ventricular ectopic activity. $\mathcal{F} \mathrm{Am} \mathrm{Coll}$ Cardiol 1983; 2: 403-10.

98 Hamby RI. Primary myocardial disease: a prospective clinical and hemodynamic evaluation in 100 patients. Medicine (Baltimore) 1970; 49: 55-78.

99 Shugoll GI, Bowen PJ, Moore JP, Lenkin ML. Follow-up observations and prognosis in primary myocardial disease. Arch Intern Med 1972; 129: 67-72.

100 Bruschke AVG, Proudfit WL, Sones FM Jr. Progress study of 590 consecutive nonsurgical cases of coronary disease followed 5-9 years. Circulation 1973; 47: 1154-63.

101 Furberg CD, Morton Hawkins C, Lichstein E. Effect of propranolol in postinfarction patients with mechan- 
ical or electrical complications. Circulation 1984; 69: 761-5.

102 Tunstall-Pedoe $\mathrm{H}$. Changing digoxin potency and cardiac mortality in England and Wales 1968-76. $\mathrm{Br}$ Heart $\mathcal{f}$ 1985; 54: 243-7.

103 Medical Research Council Working Party. Long term domicilary oxygen therapy in chronic hypoxic cor pulmonale complicating chronic bronchitis and emphysema. Lancet 1981; i: 681-6.

104 Ashutosh K, Mead G, Dunsky M. Early effects of oxygen administration and prognosis in chronic obstructive pulmonary disease and cor pulmonale. $\mathrm{Am}$ Rev Respir Dis 1983; 127: 399-404.

105 Veterans Administration Cooperative Study Group on Antihypertensive Agents. Effects of treatment on morbidity in hypertension: results in patients with diastolic blood pressures averaging 115 through $129 \mathrm{~mm}$ Hg. $\mathcal{F} A M A$ 1967; 202: 1028-34.

106 Veterans Administration Cooperative Study Group on Antihypertensive Agents. Effects of treatment on morbidity in hypertension. II. Results in patients with diastolic blood pressures averaging 90 through 114 $\mathrm{mm} \mathrm{Hg.}$ fAMA 1970; 213: 1143-52.

107 McFate Smith W, Edlavitch SA, Krushat VM. US Public Health Service Hospitals intervention trial in mild hypertension. In: Onesti G, Klint CR, eds. $H y$ pertension - determinants, complications and intervention. New York: Grune and Stratton, 1979:381-99. 